\title{
The Effect of Time Length Consumption of Carbonated Beverage on Protein and Calcium in a Sample of Healthy Iraqi Adults
}

\author{
Ameera J Al-Aaraji \\ Department of general sciences, basic EducationCollege, Babylon University, Iraq
}

\begin{abstract}
Background: Soft drink consumption has become a greatly visible and controversial public health and public policy issue. The lack of awareness concerning the ill -health consequence of soft drink consumption and lack of desire to changes this behavior could be addressed through a social marketing campaign.

Objective: This study was performed to determine the effects oflong-term consumption of carbonated soft drinks on total serumprotein (TP), albumin, globulin, totalcalcium (CaT), corrected calcium and ionized calcium $\left(\mathrm{Ca}^{++}\right)$in healthy persons.

Results: The study included 80 healthy subjects who consumed carbonated drink at different time length.The period of carbonated beverage Consumption was conversely associated with serum albumin, TP, globulin $(p<0.00)$ and $(\mathrm{CaT})(p<0.00)$ but there was no effect on the level of corrected calcium and $\mathrm{Ca}^{++}$.
\end{abstract}

Keywords: Calcium,Carbonated Beverage,Protein

\section{Introduction}

In several observational studies,intake of carbonated beverages was associated with reduced bone mass or increased fracture risk,both later in life and in children and adolescent(1).Soft drink have been banned from schools in Britain and France and in some places in the United States (2).

Infact, soft drink pose health risk both because of what they contain (extra calories, sugar and various additives) and what they replace in the diet (beverage and foods that provide vitamins,minerals, and other nutrient)(3). Soft drink consumption has become agreatly visible and controversial public health and public policy issue (2).The lack of awareness concerning the ill -health consequence of soft drink consumption and lack of desire to changes this behaviorcould be addressed through asocial marketing campaign (4).

One-half of adolescents and young adults and around one-third of adults in general report being consumers (5). One of the most global problem is the lack of awareness about the health issues associated with excessive soft drink consumption. In addition, environmental strategies relating to price, taxation, access, marketing, labelling and portion size can generally be applied only at the population level(6).

\section{Methods}

Eighty healthy subjects who consumed carbonated beverage at a variable period lengthwere enrolled in the study. Blood sampleswere collected by venipuncture, without tourniquet and were transferred into clean new plane tubes, the blood samples were allowed to clot at room temperature and sera were separated by centrifugation, and then divided into three parts.Total serum calcium was determined by the orthocresolphthaleincomplexone method using a calcium kit (7). Total protein was determined by the Biuret test and albumin levels were determined by the bromocresol purple method (7).

Instead of obtaining a crude correction for measured calcium, the same data can be used to calculate the ionized calcium according to the formula

\subsection{Ionized Calcium $(\mathrm{Mmol} / \mathrm{L})=\left[60 *\right.$ Measured Calcium $\left.(\mathrm{Mmol} / \mathrm{L})-\mathrm{K}^{\prime} / 12\right] / \mathrm{K}^{\prime}+60$}

$2.2 \mathrm{~K}=0.19 *$ Total Protein G/L + Albumin (G/L)

The corrected serum calcium can be calculated according to the formula

\subsection{Corrected Calcium $(\mathrm{Mmol} / \mathrm{L})=$ Measured Calcium $(\mathrm{Mmol} / \mathrm{L})+0.02[40 \%-$ Albumin $(\mathrm{G} / \mathrm{L})]$}

\section{Results}

The study involve eightypersons who were active consumers of caffeinated softdrinksaged(18-33) years,height (153-168) $\mathrm{cm}$. There were significant negative relation betweenlong-term consumption of soft drinksand Calcium, Albumin, total protein and globulinwith,but no relation with ionized and corrected calcium. As shown in Fig (1), (2), (3),(4) and table (1). 


\section{Figure And Table}

Figure (1): The relation between mean total calcium and period of soft drink intake

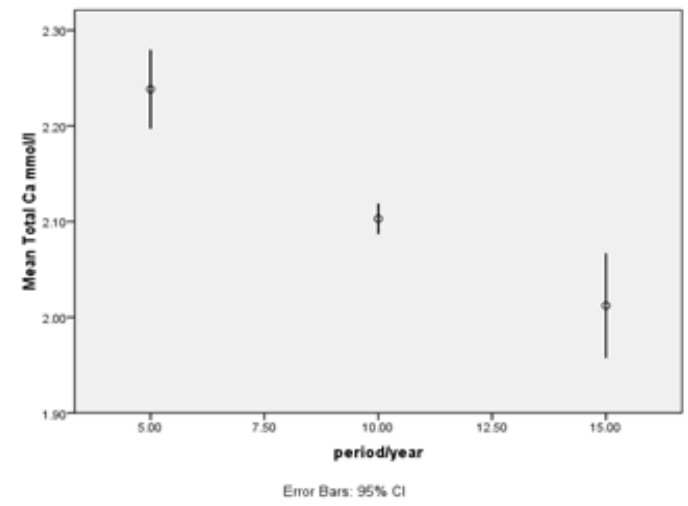

Figure (3): The relation between mean albumin and period of soft drink intake

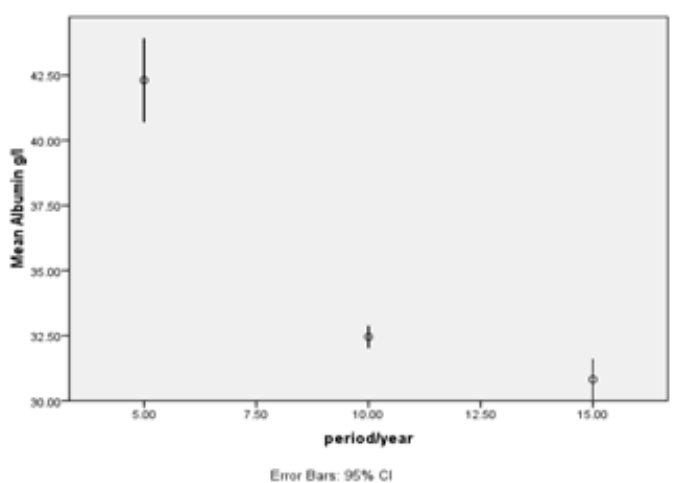

Figure (2): The relation between mean total calciumand period of soft drink intake

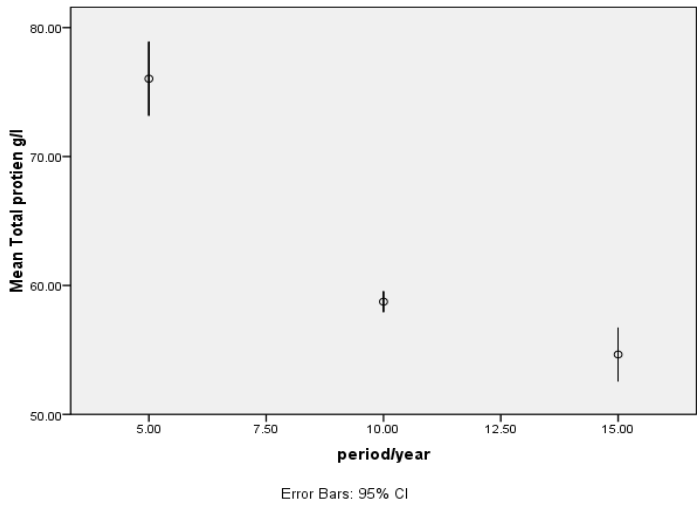

Figure (4): The relation between mean globulin and period of soft drink intake

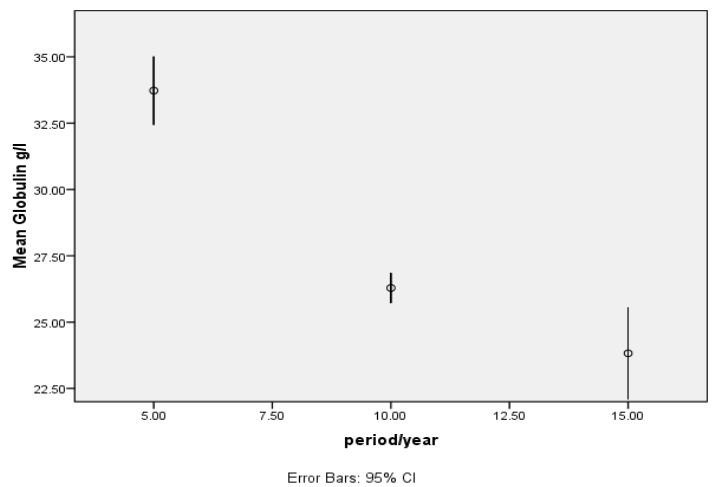

Table (1): The relation between measured parameter and long-term consumption of soft drinks with $\mathrm{p}$ value and correlation coefficient $(r)$.

\begin{tabular}{|l|c|c|}
\hline $\begin{array}{l}\text { The relation between measured } \\
\text { parameter and long term } \\
\text { consumption of soft drinks }\end{array}$ & (r) & $\mathrm{p}$ value \\
\hline Icalcium & -0.356 & $\mathrm{P}<0.05$ \\
\hline Ionized calcium & -0.2 & $\mathrm{P}<0.22$ \\
\hline Corrected calcium & -0.153 & $\mathrm{P}=0.351$ \\
\hline Total protein & -0.613 & $\mathrm{P}<0.001$ \\
\hline Albumin & -0.698 & $\mathrm{P}<0.001$ \\
\hline Globulin & -0.449 & $\mathrm{P}<0.05$ \\
\hline
\end{tabular}

\section{Discussion}

A number of studies examined links between soft drink consumption and various health outcomes, but in our society, there were little data about this.

This study show that the serum level of total calcium (CaT) was significantly and progressivelydecreased with period factor ofsoft drinks consumption.

Our results was in a good agreement with Amato D,et al and Garcia-Contreras F,et al and this may be attributed to Frequent consumption of soft drinks may increase the risk of osteoporosis especially in people who drink soft drinks instead of calcium-rich milk $(8,9)$. This calcium loss might underlie the observed connection between soda drinking and low bone mineral density (10). Studies in which women were given increasing quantities of dietary phosphorus found increases in markers of bone breakdown and decreases in markers of bone formation. Phosphorus content of colas also triggers calcium loss (11).

One problem with caffeinated beverages is that it increases the excretion of calcium in urine $(1,12)$. Drinking 12 ounces of caffeine-containing soft drink causes the loss of about $20 \mathrm{mg}$ of calcium. That loss, 
compounded by the relatively low calcium intake in girls who are heavy consumers of soda, may further increase the risk of osteoporosis (13).

Soft drinks provide large amounts of sugars (mostly high- fructose corn syrup). More recently, fructose, found in beverages that use natural sweeteners, was implicated as a possible cause of reduced calcium balance (14).

Our results was in contrast with ZalmanS (15).

From other aspect of view, there were not significant relation between ionized and corrected calciumand soft drink intake. Because the ionized calcium level in the blood stream is affected by plasma PH and soft drinks were cause acidosis, that is, less calcium is bound to protein and, therefore, more exists in the ionized form, even the total serum calcium level is lower than normal (16).

This study also show that the total protein,albumin and globulin were significantly and inversely related to time of soft drink intakeand this results was accordance with David A, thatwho found an association between sugar-sweetened sodas and albuminuria, which is a marker of early kidney damage (17).

Also was in a good relation to the study of Arun R. et al that they explain their results by the fact that intake of soft drink associated with both liver (the main source of albumin and globulin) and kidney damage (18).

\section{Conclusion}

Consumption of carbonated beverage associated with low serum calcium, totalprotein, albumin and globulin but there was no effect on the level of corrected calcium and ionized $\mathrm{Ca}$.

\section{References}

[1]. Robert P,Karen R. Carbonated beverages and urinary calcium excretion.American Society for Clinical Nutrition.2001.

[2]. Lenny R. Vartanian, PhD, Marlene B. Schwartz, PhD, and Kelly D. Brownell, PhD. Effects of Soft Drink Consumption on Nutrition and Health: A Systematic Review and Meta-Analysis. American Journal of Public Health .2007, Vol 97, No. 4

[3]. Michael F, Jacobson. Liquid Candy How Soft Drinks Are Harming Americans' Health. 2005. $2^{\text {nd }}$. Center for Science in the Public Interest Washington, D.C.

[4]. Debra H,Anna R, TimG, JimmyL, Victoria M. F. Soft drink s, weight status and health: a review ,NSW Centre for Public Health Nutrition, Sydney, Australia. 2009 .University of W ollongong Research Online.

[5]. Cynthia L. Brian K, M.D., Margaret D. Carroll M. and Sohyun P .Consumption of Sugar Drinks in the United States, 20052008.NCHS Data Brief. 71. 2011

[6]. Hector D, angan, A. R, Louie V. M. Flood \&T. Gill 2009, Soft drinks, weight status and health: a review, NSW Centre for Public Health Nutrition, Sydney, Australia

[7]. Ameera J, H.THE RELATIONSHIP BETWEEN TESTOSTERONE HORMONE AND LIPID PROFILE, PROTEINS AND SOME TRACE ELEMENTS IN THE SERA OF PATIENTS WITH PREECLAMPSIA. 2 B.Sc. Chemistry (Babylon University).

[8]. Amato D, Maravilla A, Montoya C, Gaja O, Revilla C, Guerra R, Paniagua R. Acute effects of soft drink intake on calcium and phosphate metabolism in immature and adult rats. Rev Invest Clin. 1998 May-Jun; 50(3):185-9.

[9]. García-Contreras F, Paniagua R, Avila-Díaz M, Cabrera-Muñoz L. Cola beverage consumption induces bone mineralization reduction in ovariectomized rats. Arch Med Res. 2000; 31(4):360-5.

[10]. Vondracek SF, Hansen LB, McDermott MT. Osteoporosis risk in premenopausal women. Pharmacotherapy. 2009; 29(3):305-17.

[11]. Kemi VE, Kärkkäinen MU, Lamberg-Allardt CJ. High phosphorus intakes acutely and negatively affect Ca and bone metabolism in a dose-dependent manner in healthy young females. Br J Nutr. 2006 Sep; 96(3):545-52.

[12]. Barger-Lux MJ, Heaney RP. Caffeine and the calcium economy revisited. Osteoporosis Int. 1995; 5:97-102

[13]. Juliano LM, Griffiths RR. Caffeine. In Lowinson JH, Ruiz P, Milman RB, et al. (Eds.).

[14]. Milne DB, Nielsen FH. The interaction between dietary fructose and magnesium adversely affects macromineral homeostasis in men. J Am CollNutr 2000; 19:31-7.

[15]. Zalman S. Agus, MD. : Diet Soft Drinks Deplete Urinary Calcium University of Pennsylvania School of Medicine and Dorothy Caputo, MA, RN, BC-ADM, CDE, Nurse Planner. 22, 2010.

[16]. Norma M and metheny.Fluid and electrolyte. $5^{\text {th }}$ ed. Jones \&BortlettLearing, LLC. 2012.

[17]. David A. Shoham, Ramon Durazo-Arvizu, Holly Kramer, Amy Luke, Suma Vupputuri, AbhijitKshirsagar, Richard S. Cooper Sugary Soda Consumption and Albuminuria: Results from the National Health and Nutrition Examination Survey,1999- 2004. J plos one. 2008:3(10).

[18]. Arun R, Praven KV, SheebaV . Biochemical effects of feeding soft drinks and ethanol. Indian Journal of Experimental Biology.2009. 47. 333-337. 